\title{
Military, Authoritarianism and Islam: A Comparative Analysis of Bangladesh and Pakistan
}

\author{
Md Ziaul Haque Sheikh \\ Jagannath University and South Asian University
}

\section{Zahid Shahab Ahmed}

\section{Deakin University}

\begin{abstract}
The years 1975 and 1977 witnessed a wave of de facto military regimes in Bangladesh and Pakistan, respectively. In Pakistan, General Muhammad Zia-ul-Haq operationalized the country's preexisting Islamic identity from emblematic to substantive at both domestic and international levels. General Ziaur Rahman and General Ershad of Bangladesh revived the country's Islamic identity at the domestic and international levels and reopened the space for religious fractions that were banned from politics constitutionally in the previous regime. Focusing on military regimes in Bangladesh and Pakistan between 1975 and 1990, this paper aims to bridge that gap by specifically examining the use of Islam. This study argues that dictators in both countries used Islam to support their survival strategies of legitimacy, repression, and social control. Authoritarian rulers did not have to use Islam to maintain military coherence, because of the military's culture of subordination to superiors.
\end{abstract}

\section{INTRODUCTION}

The second half of the 1970s witnessed the emergence of two military authoritarian rulers in South Asia. In 1975, after the bloody departure of Sheikh Mujibur Rahman in August and the "Sepoy mutiny" of November, General Ziaur Rahman (hereafter ZR) assumed power and became the de facto military ruler of Bangladesh (Hossain 2015, 381). He used Islam to legitimize his regime and made significant changes to

Address correspondence and reprint requests to: Zahid Shahab Ahmed, Alfred Deakin Institute for Citizenship and Globalization, Deakin University, 221 Burwood Hwy, Burwood VIC 3125, Australia. E-mail: zahid.ahmed@deakin.edu.au 
the state system, transforming the nation's identity from "secular Bangladesh" into "Muslim Bangladesh"; religious political parties were allowed in politics (Hossain, and Siddiquee 2004, 384-99), the civil-military bureaucratic nexus was built up and overall, Bangladesh revived the Islamic ideology that had guided it during the Pakistan period (19471971). This military regime was succeeded by General Hussain Muhammad Ershad in 1981, who continued to rule until 1990 and followed the same path. In Pakistan, within the couple of years, in 1977, General Muhammad Zia-ul-Haq (hereafter ZH) came to power, ousting the democratic government of Zulfiqar Ali Bhutto to become the de facto military ruler of Pakistan (Burki et al. 1991, 1). He also used Islam strategically to legitimize his military authoritarian rule. Before $\mathrm{ZH}$, state policies were largely formulated and implemented by mostly Western-educated politicians and bureaucrats, but under him, religious institutions had more authority, religious fractions were empowered and, most importantly, Pakistan's army adopted a radical Islamic ideology (Shuja 2007, 25-35). In both countries, the military rulers used Islam strategically for attaining authoritarian legitimation, strengthening political and social stability domestically to gain legitimacy at home and abroad.

Whereas ZH operationalized Pakistan's preexisting Islamic identity from emblematic use to substantive application at both domestic and international levels, ZR revived Bangladesh's Islamic identity and reopened the political space to Islamists, including the Jamaat-e-Islami (JI) Bangladesh party, which was banned from politics under the secularism adopted in the 1972 constitution. Ershad continued to build Bangladeshi identity with an emphasis on Islam and relied on the support of Islamists (Uddin 2006, 138). He amended the constitution to proclaim Islam the state religion of Bangladesh (Ibid, 138-39). Focusing on military regimes in Bangladesh and Pakistan between 1975 and 1990, this study makes a comparative analysis by taking up two questions. (i) What was the nature of the military authoritarian regimes in Bangladesh and Pakistan in this period? (ii) How and to what extent was Islam used in various regime survival strategies?

The relationship between Islam and authoritarianism has aroused much debate. Some scholars are inclined to label Islam as authoritarian and argue that Islam may be incompatible with open government. According to Michael Herb (2005) Islam and the Arab regions are both responsible for continued authoritarianism in Arab Muslim countries. Bernard Lewis (1988), Roger Savory (1989), and Donald Eugene Smith (1970) have examined the connection between Sharia and authoritarianism and argue 
that Sharia has tended to motivate people to forgo their critical thinking and right to rebel and teaches them to embrace obedience of the ruler(s) and accept authoritarianism. In this context, Daniel Pipes (1983, 28182) finds that Western ideas such as democracy and capitalism are compatible with Sharia, but ideas such as equality of some diverse groups, such as homosexuals, unbelievers, and others, do clash with Islamic culture. Similar to Pipes, Steven Fish (2002) argues that one of the factors in the democratic deficit in Muslim countries is the subordination of women. However, some scholars argue that Islam is not necessarily incompatible with democracy (Tamimi 1997; Abootalebi 1999; AlSayyed 2015), and that the creation of a dichotomy between Islam and democracy is false (Ozler and Yildirim 2008, 87-99). Abdulaziz Sachedina $(2001,139)$ finds the roots of democracy in Islam and suggests "Islam's overlapping social and religious ideals can inspire the creation of pluralistic, democratic institutions in a best Muslim global community of the twenty-first century." In this context, John L. Esposito and John Overt Voll (1996) claim that Islam is democratic because Islamic concepts of shūrā (consultation), ijmā' (consensus), and ijtihād (independent reasoning) are compatible with Western notions of democracy.

However, the rise of nationalism in Afro-Asian countries during the decline of the colonial period and the emergence of nation states in the post-colonial phase after the Second World War, in general, witnessed the decline of religion's role in politics. Nevertheless, in the last three decades, religion has reemerged as an important source of moral imperatives and has played a constructive role in national reconciliation and nation building (Sachedina 2001, 4) particularly in the Muslim world, where Islam has become the national culture and Islamic tradition has become the key to issues of national politics and social justice (Ibid, 4). Islam has remained an important source of political legitimacy as it has influenced political attitudes and shaped the collective identity of Muslim-majority states (Razi 1990, 75). The role of Islam is more crucial in the case of South Asia, which was divided based on religious identity and Islam became a determining factor in the construction of Pakistan's state identity. Islam has been persistently used as a source of political legitimacy, as it represents Pakistan's Islamic ontological reality and creates the image of India's secular or Hindu identity as "other." In the case of Bangladesh, although it started its journey as a secular state in 1972, Islam became the source of political legitimacy after 1975.

Numerous studies have examined how military rulers in Bangladesh and Pakistan used Islam to strengthen their authoritarian regimes. 
Jitendra Mishra (1981, 522) argues that South Asian military rulers "sought legitimacy through the propagation of their self-image as a set of missionary, progressive, neutral and patriotic guardians of the nation." In the case of $\mathrm{ZH}$, there is no shortage of studies on how he benefitted from strong support from the within the armed forces (Yaseen, Ahmad, and Butt 2016, 122-32) through his Islamization program, the backing of Islamists (Ahmed and Balasubramanian 2010, 93), and the geopolitical dynamics of the war in Afghanistan (Ahmed 2012, 27598). Similarly, in the case of Bangladeshi military rulers, there have been studies looking at the role of religious institutions and organizations and their relationship to the survival of military regimes of ZR and Ershad (Ahamed and Nazneen 1990). Rashiduzzaman (1978) has investigated how ZR laid the foundation for his political vision of being a civilian leader. Zillur R. Khan (1985) has examined how Islam was used by ZR and Ershad to motivate Bangladeshis and to project Bangladesh as a Muslim country, especially to the Muslim world. There is however no research that has used a theoretical framework of military authoritarianism to understand and compare the military regimes of Bangladesh and Pakistan. This paper aims to bridge that gap by examining the use of Islam as a tool in maintaining authoritarian regimes in both countries. We believe that this comparative (historical) discussion is useful to understand not just democratization and civil-military relationships in two majority-Muslim states but also the role of Islam in connection to authoritarianism. Our rationale for focusing on the ideological dimension is based on the ontological roots of today's Bangladesh and Pakistan, that is, Pakistan achieved its independence from the British Empire based on a "need" for a separate homeland for the Indian sub-continent's Muslims (Two-Nation Theory), and both states consider Islam to be the state religion. ${ }^{1}$ This paper begins by developing a theoretical framework of military authoritarianism before examining the case studies of Bangladesh and Pakistan.

\section{THEORIZING MILITARY AUTHORITARIANISM}

Since the 1950s authoritarianism studies has become a growing field, motivated by the democratic backsliding and the puzzling durability of authoritarian regimes in various parts of the world. In one of the earliest works, Juan Linz (1964) defined authoritarianism as having the following four qualities: (1) limited political pluralism that is realized through 
constraints on legislature and political parties; (2) political legitimacy through appealing to emotions to justify actions against societal evils; (3) suppression of anti-regime activities; and (4) vaguely defined executive powers. The logic behind various authoritarian regime survival strategies is what March describes as involving "the substitution of consensus for consent, unity for contestability, goal orientation for procedure and authenticity for actual representation" (2003, 210). Paul Brooker (2009, 1) says that non-democratic regimes "display a bewildering diversity: from monarchies to military regimes, from clergy-dominated regimes to communist regimes, and from seeking a totalitarian control of thought through indoctrination to seeking recognition as a multiparty democracy through using semicompetitive elections."

Among these typologies, military authoritarianism was a prominent form of non-democratic governments in the twentieth century. Eric A. Nordlinger $(1977,6)$ finds that after the end of the Second World War and in the wake of democratization, militaries intervened in approximately two-thirds of the more than 100 non-Western states, and in the 1970s controlled the government in about one-third of these countries. Many attempts have been made to explain why and how military authoritarianism emerges. Samuel Edward Finer $(2002,166)$ identifies five different forms of military regimes: (i) direct—openly military rule by a military junta or military government, with leading military officers installed as the country's president and/or government ministers; (ii) direct, quasicivilianized-military rule clothed in evidence of civilian support; (iii) indirect limited-where the military exerts control over the government only intermittently and only to secure limited objectives; (iv) indirect complete-continuous military control over all activities of the civilian government; and (v) dual—a two-pillar regime - the army is one and the civilian party or the organized civilian support is the other. In this dual regime, the ruling military oligarchy or the despot is the head of both (Ibid, 165-6). Amos Perlmutter (1977, 104-5) also classifies military authoritarian governments but suggests there are three types of military regimes: arbitrator; ruler; and party-army. While the "arbitrator type" accepts existing social order, shows willingness to return to the barracks after disputes are settled and has no independent political organization and a lack of desire to maximize army rule, the "ruler type" rejects the existing order and challenges the legitimacy of it, the military has a political organization and tends to maximize army rule (Ibid, 107-8). Nordlinger $(1977,24)$ views the "ruler type" of military ruler as one that attempts to "not only control the government but dominate the 
regimes, sometimes attempting to control large slices of political, economic and social life through the creation of mobilization structure." The party-army type sits in the middle of the arbitrator type and ruler type. Perlmutter $(1977,105)$ suggests the "structural characteristic of this type is the presence of a political party, whether created or taken over by the military." He has added, "Evolving from a ruler-type regime, it sees a politically neutralized military return to the barracks and leave the regime in the hands of a military leader who has an official party at his disposal" (Ibid, 105).

After applying Linz's four characteristics of the authoritarian regimes of Brazil, Chile, Uruguay, and Argentina, George Philip (1984, 17) finds that there are "two tracks" of military authoritarian regime. "On the inside track, there is the military elite itself. As long as this remains united, it can generally impose its will on the rest of society." Philip $(1984,17)$ argues that "the military elite will almost certainly split at an early stage over the question of repression-how much is applied and how powerful should the 'repressive' officers be allowed to become?" Once the military elites consolidate their power, they seek a second track and, according to Philip, this track is related to "the political acceptability of the regime." He believes that after consolidating their hold over the government, a military ruler seriously moves away from oppression, seeks some broader support from civilians and seeks legitimacy for the regime (Ibid, 17).

However, based on the theoretical discussion presented above, we have found that there are prominent survival strategies employed by authoritarian regimes, including for instance, the creation of military coherence through internal purges, repression, social control, and legitimizing strategies (e.g., controlled elections, party-building, and international support). We divide these survival strategies into three analytical sections. The first focuses on military coherence. Studies on military dictatorship have argued that discipline and obedience of authority are part of the military culture and play a crucial role in achieving the objective of military coherence under particular authoritarian rules (Finer 2002). Other scholars further explain this institutional dynamic, arguing, "All individuals in the military go through training, and incentives to enforce the obedience of subordinates to superiors are built into every aspect of military institutions" (Geddes, Frantz, and Wright 2014, 147). The second section covers the survival strategies of repression and social control. There can be various dimensions to repressive regimes, but overall a key purpose of using illegitimate force is to crush any opposition threatening the survival 
of oppressive regimes. Force can be used in various ways, for example, through public expressions of justice that terrorize the masses, or through repressing freedom of speech (Kasparov and Halvorssen 2017). Various repressive strategies aim to discipline the population at large (Rørbæk, Skaaning, and Tolstrup 2014, 3). However, in some cases, repression is an adequate tool for social control (Kienscherf 2016, 1179). In those cases, social control can be achieved through the lens of pacification targeting specific individuals, groups and populations through a combination of coercion and consent (Ibid, 1179). Finally there are legitimizing strategies. An immediate challenge for any authoritarian regime is gaining legitimacy at home and abroad. March defines legitimation as "the attempt to transform the fact of obedience into the duty to obey" $(2003,210)$. Legitimacy has been considered an important factor in various democratic regimes but there is a tendency to believe a normative formulation of legitimacy is inconsistent with military authoritarian regimes, as a military leadership does not rely on civilian support (Hechter 2009, 279-88). Undeterred by this idea, the scholarship of authoritarian persistence as discussed by Johannes Gerschewski (2013), Robert Mayer (2001), Dingxin Zhao (2009) and Mariya Y. Omelicheva (2016) has brought attention to the question of legitimacy in authoritarian regimes. Ideology and culture, performance of government history, and external recognition are generally treated as sources of legitimacy of a military regime.

\section{ISLAM AND AUTHORITARIANISM: THE CASES OF BANGLADESH AND PAKISTAN}

Despite many instances of authoritarian rules in the Muslim world, scholars have argued that Islam is not incompatible with democratization (Fish 2002; Chen and Yang 2016). While there is a widespread agreement that Islam is compatible with democracy, there is also a point of view that Islam has correlation with dictatorships (Anckar 2012). As suggested earlier, similar to other sources of political legitimation, Islam can be instrumental in Muslim-majority countries, appealing to Islamist sentiments to bolster the legitimacy of military authoritarianism. We will now analyze this in relationship to the selected military rulers in Bangladesh and Pakistan. In this analysis, we examine if/how religion (Islam) was used as a regime survival strategy to justify social and political transformation linked to the three survival strategies of authoritarianism. 


\section{THE CASE OF BANGLADESH}

In independent Bangladesh, democracy was adopted in the 1972 constitution as one of the fundamental principles of state policy. Within 3 years, the political leadership eschewed the principle of democracy and Sheikh Mujibur Rahman (hereafter SMR) established a one-party authoritarian regime through Bangladesh Krishak Sramik Awami League (BaKSAL). After his assassination in 1975, several military coups and countercoups occurred that had far-reaching implications for the future of Bangladesh. The one-party civil authoritarian regime shifted to military authoritarian regimes during 1976-1990 under ZR (1976-1981) and General Ershad (1982-1990). Both military regimes followed the survival strategies to prolong their authoritarianism.

\section{Military Coherence}

In analyzing the nature ZR and Ershad's military authoritarianism, Philip's two-track argument is relevant (Philip 1984, 17). At the initial stage, ZR faced a number of coup attempts, including those led by Brigadier Khaled Msharraf, and Colonel Shafat Jamil. ZR was able to successfully control the military elites and gradually moved to establish a second track of military control. Similar to ZR, Ershad was also able to overturn the coup attempt by Major General Abdul Manzoor in 1981 and showed his loyalty to the civilian President Abdus Sattar. But after consolidating his position among the military elite, he became the Chief Martial Law Administrator in 1982. In keeping with Philip's first track, both ZR and Ershad initially consolidated their power with military elites before implementing the army's pre-formulated approach toward civilians, fulfilling Philip's second track to achieve political acceptability of the regime, gaining legitimacy at home and abroad. Rashiduzzaman $(1978,134)$ explains that there were two main options for ZR to consolidate power: to leave politics and transfer power to the civilian government or to continue to play a political role oscillating between an authoritarian system and some kind of controlled democracy. ZR, at his first broadcast to the nation on November 11, 1975 claimed that he was a "soldier," not a politician. However, he gradually became the latter, placing himself in a self-led authoritarian regime through a controlled democracy. On November 30, 1976, he assumed the post of Chief Martial Law Administrator (Islam 1984, 557). Then on April 21, 1977, he took over 
the presidency. Both ZR and Ershad used traditional survival strategies for establishing military coherence at the initial stage of their military rule. Islam did not play any significant role in creating their military coherence.

\section{Repression and Social Control}

We can examine the various reforms and policies of ZR and Ershad that consolidated their authoritarianism through Perlmutter's approach. Similar to ZH in Pakistan which we discuss later in the paper, ZR's strategy consisted of "witch-hunt and concerted drive against those civilian groups which they had once overthrown" (Mishra 1981, 527). Despite his occasional tactical praise for SMR, ZR had a policy of persecuting supporters of SMR's legacy and engaged right wing and anti-SMR factions as his political support base (Ibid, 527). The civil-military bureaucrats had come to occupy prominent portfolios in the state apparatus with the overthrow of SMR (Islam 1984, 559). On the one hand, ZR systematically deployed military officials in the civilian administration (Wolf 2013, 16-17), on the other hand, he emphasized the theme that "political and administrative accountability of the government to the people must be achieved through public participation across the whole spectrum of the governmental policy-making process, particularly at the local level of government" (Khan 1981, 559).

In the context of ZR's social control survival strategy, Kienscherf idea of pacification or liberal social control is relevant. In addition to repression for social control, ZR focused on pacification by targeting specific individuals, groups, and populations through a combination of coercion and consent. ZR strategically used right wing and anti-SMR fraction for not only controlling his own government but dominating the regimes and attempting to control large fraction of political, economic, and social life that ushered to establish a sustainable right wing and anti-AL political base in Bangladesh. Whereas ZR built mostly a "ruler type" regime, rejecting the existing political and ideological order and building a political organization to maximize his rule, Ershad established a "party-army type," accepting and continuing the existing political order before attempting to establish his own "ruler type" regime, consolidating his position at the top. Similar to ZR, he continued the systemic deployment of military officials in the civilian administration (Kochanek 1993). In addition, by introducing a quota-system for military officers in civil posts, he enhanced the institutionalization of the Army's political role (Robinson 1989). 
Ershad's effort was to controlling his own government rather than dominating the regimes and control the large fraction of political, economic, and social life.

\section{Legitimizing Strategies}

The two military rulers, ZR and Ershad, demonstrate Finer's hypothesis that military rulers need popular support to prolong their rules (Finer 1997). In a referendum held on May 30, 1977, 98.88\% of voters voted "yes" to the question of whether ZR should continue as President (Baxter and Rashiduzzaman 1981, 486). However, as ZR recognized that this referendum did not provide enough legitimacy to prove substantial public support, he arranged a presidential election on June 3, 1978. In this election, he contested against General Osmany, the candidate supported by the Awami League (AL); ZR secured $76.63 \%$ of votes to Osmany's $21.7 \%$ (Ibid, 486).

As Islam had been an ongoing part of nation-building processes and debates in Bangladesh (Hossain 2015, 381), ZR and Ershad chose to use religion instrumentally to legitimize their rule through widespread public support. ZR's reforms began with changing the constitutional identity of Bangladesh from secular to Islamic. After independence, the secular constitution under SMR (1972-1975) defined the ideological image of Bangladesh as "Bangali," based on the ethno-linguistic secular ideology that negated the idea of a two-nation state to legitimize its separation from West Pakistan. This construction presented the "Bangali" as a "pro-liberation force" and the "Muslim Bangladeshi" as an "anti-liberation force." However, there was a persistent misconception in Bangladesh that secularism meant either the absence of religion (atheism) or presence of Hinduism (Bhuiyan 2017, 204-27; Yasmin 2013). The day secularism was enshrined in the constitution, a public procession occurred demonstrating against the addition with the slogan "Joy Bangla joy-heen, Lungi chere dhutipin." This slogan asserted that the historical AL slogan of Joy Bangla (victory to Bangladesh) had turned meaningless in independent Bangladesh and that Bangladesh would be free of "victory" and, because of the adoption of secularism, the historical "lungi" donned by Bengali Muslim men would be substituted with "dhuti," the traditional dress of Hindu men (Ibid). The government created the image of the religion-driven "Muslim Bangladeshi" as the representative of the "other" (Two-Nation Theory holder) identity, by saying 
that they belong to the identity of Islamic Pakistan. However, "Muslim Bangladeshis" had enough space to represent its distinct Muslim political and societal identity in Bangladesh. According to Riaz (2018, 305), "Since the beginning of the expansion of Islam in Bengal variations in interpretations of religion and rituals have become embedded into the ethos of its adherents; this remains the mainstay of Islam in Bangladesh." This Islam-oriented identity was socially strong enough to shape citizens' perceptions and affect political debate in Bangladesh after 1975 (Khan 1985, 834-51; Ahamed and Nazneen 1990, 795-808). ZR capitalized on this to construct the ethos and values of Bangladesh based on the perception of division between Hindu and Muslim culture, in line with the Two-Nation Theory (Mannan 2015) to gain domestic political acceptance and to legitimate his rule. He promoted and patronized the Muslim Bangladeshi and created the image of the ethnic and seculardriven Bengali identity, representative of the "other" (Hindu) identity, saying that they belonged to the identity of Hindu India or secular India (Brasted 2012, 116). ZR was determined to amend the constitution.

With the Proclamation (Amendment) Order, 1977, ZR inserted Islamic elements into the preamble of the constitution. The words "Bismillah-arRahman-ar-Rahim" (In the name of Allah, the Beneficent, the Merciful) were added to the start of the constitution. Article 6 was modified, now declaring that "citizens of Bangladesh shall be known as Bangladeshi."2 Article 8 declared (1) "The principles of absolute trust and faith in the Almighty Allah, nationalism, democracy and socialism meaning economic and social justice, together with the principles derived from them as set out in this Part, shall constitute the fundamental principles of state policy." 3 Article 8(1A) also states that "Absolute trust and faith in the Almighty Allah shall be the basis of all actions." 4 ZR also had abolished the erstwhile article 12 (regarding secularism) and article 25 was modified with the insertion that the State shall endeavor to consolidate, preserve, and strengthen fraternal relationships among Muslim countries based on Islamic solidarity. ${ }^{5}$ Moreover, article 38 of 1972 s constitution was modified to omit: "Provided that no person shall have the right to form, or be a member or otherwise take part in the activities of, any communal or other association or union which in the name or on the basis of any religion has for its object, or pursues, a political purpose." With this, ZR legalized the use of Islam for political purposes and his proclamations were assured by the fifth amendment of the constitution in 1979, thus diluting the secular identity of the constitution. ZR created a domestic fear of the secular Bengali, aiming to transform Bangladesh identity from ethno-linguistic 
Bengali culture and secular polity to religio-cultural Muslim Bangladeshi identity and Islamic polity. According to Bhardwaj, for countering secularism, ZR criticized SMR for making Bangladesh into a satellite state of Hindu India (Bhardwaj 2011, 18).

The trend of using Islam as a tool was continued under Ershad. He made the eighth amendment of the constitution in 1988, inserting article $2 \mathrm{~A}$, which stated "the state religion of the Republic is Islam but other religions may be practiced and harmony in the Republic." $\mathrm{ZR}$ started to Islamize the constitution but Ershad changed the constitutional identity from secular to Islamic by inserting Islam as the state religion of Bangladesh. The aim of this amendment was to revive the Islamic ontological reality and patronize the "Muslim Bangladeshi" group that would help to sustain the public support the military authoritarian regime. It created a space to reorient the use of Islam for political purposes. Uddin sees the significant changes under ZR as reviving an Islamic-oriented Bangladeshi nationalism to gain the support of religious and conservative parties (Uddin 2006, 131); Ershad continued this trend.

To achieve his political ambitions, ZR gradually developed a political party that provided a much better platform to promote Islamic symbolism and Bangladeshi nationalism. A "political front," a civil-military alliance was formed on December 15, 1977 and later it became Jatiyobadi front, ${ }^{7}$ a nationalist alliance to merge all recognized political parties (Mishra 1981, 522-46). On September 1, 1978, ZR attempted to form a political party, the Bangladesh Nationalist Party (BNP), by uniting the Jatiyotabadi Gonotantrik Dal (Nationalist Democratic Party), National Awami Party (B), and the United People's Party, Muslim League and the Minority Party. However, at the initial stage, the BNP had no grassroots base and no internal democracy. To establish a grassroots base, ZR used the Bangladeshi nationalist flag, adding Islamic color to promote the party's ideology and draw in a support base to prolong his authoritarian rule (Ibid, 338-39). He successfully used Islamic symbolism for his political gain. Many members of left-leaning political parties with links to China and anti-India sentiment joined the BNP (Hossain 2015, 381). Although ZR promulgated the Political Parties Regulation, 1976 for the reintroduction of the multi-party system he simultaneously rehabilitated the proIslamic political parties that were banned during the erstwhile AL regime (Bhattacharya 1999, 196).

After assuming power in 1982, Ershad maintained this party-army type military regime until 1986. Initially, his intention was to legitimize his military rule through civilianizing the government (Sen 1994, 122). 
However, rather than rejecting the existing ideological and political structure, he chose to continue ZR's policy and relied on support from religious and conservative parties (Uddin 2006, 138). He continued to proliferate Bangladeshi nationalism with an emphasis on Islamic identity. After 18 months of party-type military rule, he began establishing a ruler-type military rule. On November 27, 1983, Janadal was formed with Ershad's support. Later, members of Janadal, Muslim League, Ganatantri Dal, and United People Party along with members of the BNP, including Shah Azizur Rahman, formed the Jatiya Party and Ershad became party president. However, it was very difficult for him to establish a ruler-type of military regime, as the dominance of two major political parties, AL and BNP, thwarted his parliamentary aspiration (Abhilash 2012, 91). Ershad therefore focused more on Islamic elements in his politics, including through declaring Islam the Bangladesh's state religion.

As Lewis (1988), Savory (1989), and Smith (1970) show, Islam has tended to motivate people to forgo their critical thinking and right to rebellion and to teach them to embrace obedience toward the ruler(s) and accept authoritarianism. With this view, both ZR and Ershad domesticated Islamic ideology. They thought that an imagined Islam-oriented "Muslim Bangladeshi" identity could be appropriated by its citizen at the societal and individual levels through the domestication process. State identity became integrated into everyday life, in the belief that this would create a congenial environment for adopting this identity. Symbolic measures were taken to promote Islamic identity, for example, Qur'anic verses and the Prophet's advice were displayed on posters hanging in government offices, officials patronized religious occasions like Eid-e-Milad un-Nabi, Muharram, Shab-i-Barat, and azan (call to prayer) and principles of Shariah were to telecast on radio and television (Ahamed and Nazneen 1990, 795-808). The government's Cabinet created a new division for religious affairs. The Islamic Academy was transformed into the Islamic Foundation with extensive research facilities (Ibid). A new Islamic University was established with financial support from the Organisation of Islamic Cooperation. Ershad continued domesticating anti-Islamic identity fear; he continued to strengthen Islamic identity. He established a Zakat fund and promoted Islamic learning, introducing Islamiat (Islamic studies) into the curricula from grade one (Ibid). He frequently visited mosques and Islamic shrines, met imams (Islamic religious leader) and peers (Sufi masters or spiritual guides), and allocated liberal grants to these religious institutions (Ibid). After a 
meeting with Jamiat-ul-Muderressin on January 10, 1988, Ershad stated that Islamic principles would be the base of cultural life in Bangladesh.

Alongside these domestic activities, ZR and Ershad reoriented Bangladesh's foreign policy to gain political acceptance and legitimacy domestically and externally. Both ZR and Ershad presented the secular Bengali identity as a pro-Indian or pro-Hindu identity. This apprehension "turned into an anti-India sentiment, given the fact that Indian domination over Bangladesh... was popularly perceived as the domination of Hindu India" (Mannan 2015, 87). ZR began using the Islamic card to strengthen anti-Indian sentiment, which had persisted during the SMR regime. ZR portrayed Indian influence as a danger to the independence and sovereignty of Bangladesh, accusing India of sheltering pro-SMR guerrillas, known as Kader Bahini, who conducted cross-border attacks from the Indian side (Pattanaik 2012, 22). On May 1, 1976, ZR said:

We do not want to interfere in the internal affairs of others. Likewise, we want that no other country will interfere in the internal affairs of Bangladesh.... If there is aggression on us to seven and half-crore people of the country will rise to one man and resist it and defend the independence (Bangladesh Observer May 2, 1976).

Ershad continued with anti-Indian foreign policy, supporting Pakistan's position on Kashmir. In 1990, Ershad, in a public statement, deplored the killing of Muslims in the Indian-administered Kashmir and asked India to exercise maximum restraint on the Kashmir issue (Asian Recorder 18-24 June 1990). By domesticating fear of a pro-Indian, anti-Islamic secular identity, or Hindu identity as an enemy of Bangladesh (Maniruzzaman 1990; Hashmi 1994, 103-4), ZR and Ershad strengthened the Muslim societal and political identities of Bangladesh that could enhance their political acceptance at the domestic level and abroad. ZR also improved Bangladesh's relationships with Pakistan and the Muslim world (Ummah). He once claimed, "We have religious, historical and cultural relations with all the Muslim countries of the world and we want to further our relations with them" (The Bangladesh Observer May 2, 1976). Ershad continued good relationship with Pakistan and was awarded Pakistan's highest civilian award (Nishan-i-Pakistan) as a tribute to his contribution to brotherly relationships between Bangladesh and Pakistan, and his leading role in establishing the South Asian Association for Regional Cooperation (Rizvi 1993, 55). Both ZR and Ershad held up their good relationship with Pakistan 
and the Muslim world as a representation of the country's Islamic identity at domestic and international levels, consolidating their "political acceptance and legitimacy" at domestic and international levels. As Bhuian MD. Manohar Kabir (1999, 23) explains:

...they want to give the system an ideological and political institutional shape that would sustain the reproduction of the system. It is also true for various Bangladeshi military-authoritarian regimes which used religion (Islam), in their attempts for political legitimization.

However, ZR, despite successfully gaining public support, was unable to ensure the backing of the armed forces and that is what led to his assassination. He was not able to eliminate all opposition and finally himself killed by a group of army officers (Franda 1981, 1387). He wanted to become "a truly civilian politician" (Ibid, 1387). Ershad, on the other hand, achieved strong support from the armed forces, similar to the case of $\mathrm{ZH}$ of Pakistan. He prolonged his authoritarian regime by maintaining the check and balance between military officials and civil politicians.

\section{THE CASE OF PAKISTAN}

Islam has been at Pakistan's core since its foundations were laid. It became an Islamic Republic in 1956 with its constitution subscribing "to a diluted form of pluralism" (Hoodbhoy 2016, 36). The blueprint "Objective Resolution" for the Islamic republic was prepared during the era of Liaqat Ali Khan, Pakistan's first prime minister. While the Objective Resolution provided hints to religious (Islamic) alignment of the government, there was no mention made to sharia in the document (Zaidi 2003, 102). Zulfiqar Ali Bhutto, however, initiated the process of Islamization in the 1970s, but its intuitional form was the product of the next regime. The focus of this section, however, is the era under General $\mathrm{ZH}$ and his use of Islam as a tool to gain legitimacy at home and abroad. Crucial to this is understanding $\mathrm{ZH}$ 's type of rule. It was an amalgamation of many types. If we look at Perlmutter's approach to military regimes (Perlmutter 1977), ZH's rule began as arbitrator type but shifted to a "ruler type," consolidating his position at the top. Below we analyze the various reforms and policies that helped $\mathrm{ZH}$ consolidate his power to become the longest serving head of the state in Pakistan. 


\section{Military Coherence}

A first step for any dictatorship is to ensure that its support base, the military, is solid. This is Philip's $(1984,17)$ "first track," on the inside, focusing on the military elite itself. ZH also initially focused on the top tier of the armed forces, providing benefits to serving and retired generals both financially and professionally. Despite some initial challenges from within the army, $\mathrm{ZH}$ devised a strategy to gain the full confidence and support of the armed forces. His first step was to create the so-called "Jullundur lobby" within the army, comprising people of the same heritage, hailing from Jullundur in today's Indian Punjab. ZH aggressively reacted to possibilities of a coup against him by arresting military officers, including a retired major general. He showered those loyal to him with key positions and punished his opponents with powerless postings. By 1981, all provincial governors were serving lieutenant generals (CIA 1981, 7). $\mathrm{ZH}$ played army politics very well, putting his supporters in key military positions. ${ }^{8}$ He gained further support from top military officers with promises of modernizing the armed forces with weapons, for example from U.S. military aid, and job security. ZH fixed a quota of $10 \%$ in civil services for retired military officers and reserved seats for them in universities and professional institutions. In addition, $\mathrm{ZH}$ initiated schemes to give agricultural land and residential plots to military officers (Zahid 2011, 20). According to S. Akbar Zaidi (2017), "the military, like never before, had become a corporate entity, involved in all kinds of activities: legal and illegal. Perhaps never before [the ZH era] had Pakistan's armed forces been drawn into a nexus of military might, money, corruption and privilege." These measures served the purpose of garnering $\mathrm{ZH}$ support from the armed forces, as is reflected in a 1983 report of the Central Intelligence Agency:

President Zia-ul-Haq faces no substantial challenge to his rule for now ... The President ultimately depends on the Army to remain in power. Although a significant sentiment exists in the military for an end to martial law, most senior officers strongly believe the Army should remain united behind General Zia (CIA 1983, iii).

\section{Repression and Social Control}

$\mathrm{ZH}$ built on the Islamization that had been initiated during his predecessor's time as a repressive strategy, having clear elements of terror and 
social control. The legal changes labeled as Islamic were a clear manifestation of a mullah-military alliance in Pakistan serving the military regime's desire to maintain its power by pleasing right-wing Islamists, such as the Jamaat-e-Islami. The Islamists had long been calling for the implementation of a strict form of sharia in Pakistan, and an alliance with $\mathrm{ZH}$ provided them with a clear opening to achieve some of their goals.

The mullah-military alliance under $\mathrm{ZH}$ led to legal changes aimed at transforming Pakistan into a theocratic state. The $\mathrm{ZH}$ regime used all possible means, such as the media and education, to spread Islamization. Shahid Javed Burki argues that "with the resurgence of Islamic fundamentalism ... this art form [television drama] was to suffer a serious setback" (1986, 33). The state-run television channel (PTV) was used for spreading both political and religious messages and then; the Ministry of Information directed PTV's female newscasters to appear on TV with dupatta (scarf) covering their heads and without make-up. These conservative practices were not only enforced on media professionals but dress codes were implemented for public personalities and other women and girls, for example women working in government institutions were required to wear dupatta to cover their heads and female students above the age of 12 were required to wear chadors/shawls (Hashmi and Batool 2019, 80). To popularize these legal and social changes, the idea of "chaadar and chardiwari" (literal translation: the veil and the four walls) was promoted to justify that women's place was in the home (Qadeer 1997, 751). Beyond dress code, sharia or Islamic ideas of morality were used to justify restrictions on music, dancing and red-light areas, such as the Heera Mandi in Lahore (Hussain 2007).

From the very beginning, the $\mathrm{ZH}$ regime had made it clear that there would be strict punishment for anyone who was critical of the government. The direct victims of this were politicians and journalists. An early visible sign of widespread repression included political prisoners, who, according to one estimate, numbered between 300 and 500 in 1982 and who were tortured (Kaufman 1982). At the time the PTV was the only TV channel and media censorship was mostly imposed on the press. "If you did not heed warnings, you faced imprisonment or the possibility that your publication would be shut down" (Aslam and Ali 2009, 32).

Another strategy was to use Islamization as a tool for social transformation, which $\mathrm{ZH}$ believed was necessary to find the social evils facing Pakistan. Under General ZH, Islamization led to promulgation of Islamic laws in the country which continues to have implications for the 
present day Pakistan. In 1980, Islamabad was site of the first demonstration by Shias against the implementation of the ZH's Zakat and Ushr Ordinance (Warde 2010, 116). Shias demanded exemption from paying Zakat $^{9}$ to the state and the government had to agree (Iqbal 2014). According to Mukhtar Ahmad Ali (2000, 33), the successful protests in Islamabad became a factor in deteriorating Shia-Sunni relationships in Jhang-presently a hotspot of sectarian violence-where both communities had lived side by side for generations. Ahmadiyah, who were already declared non-Muslim during Zulfiqar Ali Bhutto's era, were now faced with more restrictions, for example, the $\mathrm{ZH}$ government had prohibited the Ahmadiyas from calling their prayer places mosques and from possessing and reading the Qur'an as well as from using Muslims ways of greeting (Rehman 2017). While ZH was inspired by the religious values of Saudi Arabia, Pakistan was undergoing structural changes due to its strategic partnership with the United States and Saudi Arabia for so-called jihad against the Soviets in Afghanistan. Jamaat-e-Islami (JI) and Jamiat Ulema-e-Islam (JUI) were at forefront of jihad and Islamization at home and abroad (Afghanistan) for Pakistan's political ambitions (Ahmed 2012, 275-98).

ZH's legal reforms under Shariah were aimed at enhancing his support from Islamists. This, in a way, served the purpose of what scholars argue to be a key goal of authoritarian regimes implementing Shariah, "to teach people to embrace obedience towards... authoritarianism" (Smith 1970; Lewis 1988, 821-44). Soon after taking control of the country, ZH embarked on his Islamization mission and labeled it a pre-condition for democracy in Pakistan (Kanwal 2015, 46). Burki argues that under ZH's "tutelage, a comprehensive effort was commenced at the grassroots level (the education system) via madrassas/madaris (religious schools) and a revamping of the curriculum of government schools, to indoctrinate future generations to view the imposition of strict Shariah laws" (Burki 2016, 116). These strict Shariah laws included the Zina Ordinance and the Hudood Ordinance of 1979. The military regime used the label of "Nizam-i-Mustafa/Nizam-i-Islam" (the order of the Prophet/Islamic system) to Islamize the nation. For ZH, politics and theology went hand in hand and he was therefore comfortable in his alliances with Islamists (Awan 2016, 37). In ZH's Islamization, reform of the legal system played a central role. In 1978, he established the Shariat Appellate Benches under the country's four high courts. The benches were tasked with judging legal cases using Shariah or teaching of Quran and Sunnah. While announcing the establishment of the Shariah benches, 
ZH said "Every citizen will have the right to present any law enforced by the government before the 'Sharia Bench' and obtain its verdict whether the law is wholly or partly Islamic or un-Islamic" (Wasti 2009, 291). As another step in Islamizing Pakistan, $\mathrm{ZH}$ formulated the ninth amendment to the Pakistan Constitution. In 1980, the Shariat Appellate Benches were abolished and the Federal Shariat Court was established. $\mathrm{ZH}$ directly controlled the Federal Shariat Court by appointing its judges. Although supported by conservative ideals of Islam and Islamists in Pakistan, ZH's actions were not free from criticism. That is when he had to use repressive strategies. The Hudood Ordinance, in particular, led to a lot of criticism of the government and to demonstrations. Force was used to crush several of these demonstrations, including one organized by the Pakistani women's resistance movement on Pakistan's National Women's Day in 1983 in Lahore (Imran and Munir 2018).

$\mathrm{ZH}$ effectively employed Islamization through a range of measures to secure legitimacy and stay in power. This included policy reforms and actions, and personal promotion as a devout Muslim. The educational reforms came in many shapes and sizes but the ultimate aim was Islamization that suited ZH's domestic and foreign policies. While the jihad against the Soviet suited ZH's Islamization through Saudi funding for Islamic institutions, especially madrassas, at home, Ispahani argues that "Zia carefully nurtured his image as a man of Allah, with televised attendance of prayer congregation and annual pilgrimage to Mecca" (Ispahani 2017). From the very start of his administration, he promoted himself as a "solider of Islam" (Zaidi 2017). He openly criticized the school textbooks and initiated their Islamization in 1979, playing into the hands of his political allies, Islamists, who were outright supporting ZH's reforms. The regime embarked on the mission of national identity formation with a key emphasis on Muslim heritage, which involved a special focus on the Muslim history of Pakistan. While history courses were revised to focus on Muslim rulers in the Indian Sub-continent, for example Muhammad bin Qasim, the government also introduced Pakistan Studies into secondary schools and universities to promote patriotism among the youth (Zahid 2011, 16).

Penalties for the various legal reforms labeled as according with Sharia were implemented through a strict and public display of punishment. This served the dual purpose of Islamic justification for such acts and terror among the masses, especially opponents. Blasphemy laws were introduced by the $\mathrm{ZH}$ regime in 1985 , with the death penalty given to those found guilty of insulting the Prophet Muhammad. The Hudud laws 
were also seen as in accordance with Islam, with strong punishments, including death sentence. In addition, judicial amputation for thefts and armed robbery and flogging for consuming alcohol were applicable across Pakistan (Franck and Nyman 2003, 113).

\section{Legitimizing Strategies}

Despite claims he would transfer power to the civilian leadership, ZH was used all possible strategies to consolidate his power. Soon after taking power on July 5, 1977, he said "that he had no political ambitions whatsoever, and that he would leave his post of Chief Martial law Administrator after three months" (Zaidi 2017), but that never happened -his control lasted for around 11 years. Soon after taking power, ZH had also promised that he would restore some form of democracy "as close to Islam as possible" but in the beginning of the 1982 there were visible signs of him backing away from this stated goal of his regime and expanding his authority (Kaufman 1982).

A first step toward consolidating power was the presidential referendum of 1984. The referendum was not only rigged, with election staff stamping the ballot papers instead of voters, but its key "yes/no" question was very ambiguous: Do you support the process started by General Zia-ul-Haq to bring the Laws in consonance with Holy Qu'ran and Sunnah? (Kanwal 2015, 45). A "yes" vote was automatically translated into support for Islamization under $\mathrm{ZH}$, even with a low turnout of $10-15 \%$ (Zahid 2011, 18). Still, leaders from around the world congratulated $\mathrm{ZH}$ because many countries were happy with his full support for the Afghan-Soviet War. He then created the Majlis-i-Shoora, a sort of a non-democratically selected parliament, with his own handpicked members, including mullahs, retired generals, and technocrats. While this helped him increase his political support among Islamists, the Majlis-i-Shoora could not help him gain legitimacy. Like the dictators in the past, $\mathrm{ZH}$ also preferred local government through elected local bodies at district and union levels to show that he was interested in decentralizing the governance system (Ibid, 18).

Contradictory to what Brooker argues about non-democratic regimes seeking recognition through multiparty democracy (Brooker 2009, 1), $\mathrm{ZH}$ only tolerated general elections on a non-party basis. This is because for $\mathrm{ZH}$, political parties were a major problem for Pakistan. $\mathrm{ZH}$ further justified his stance saying that there is no concept of political 
parties in Islam and that elections on a party basis would derail Islamization (Kanwal 2015, 46). In the early years of his rule, ZH placed a range of restrictions on political parties with many politicians being "placed under various forms of restrictions" (Zahid 2011, 9). While the Pakistan Peoples Party faced the brunt of ZH's aggression, other parties became his natural allies, including the Pakistan Muslim League, and JI. It is interesting that ZH so clearly moved to the second track so long after implementing the first track of controlling the military elites. Despite his claims that he would transfer power to civilians, $\mathrm{ZH}$ kept postponing the elections and once said it was not "written in the Quran that elections were to be held at a given date" (Zaidi 2017). The 1985 elections on a non-party basis was a step toward what Philip $(1984,17)$ calls the "second track," an attempt to gain political acceptability for the regime. For ZH however, it was not a complete win, as almost half of his nominees from the Majlis-i-Shoora did not survive the general elections. For example, ZH's preferred party, JI, had run candidates in 63 seats of the National Assembly but won only eight of these (Kanwal 2015, 47). With the constitutional reforms, ZH only shared a limited power with the democratically elected prime minister, but held the real power as both head of state and the chief of army staff. As an outcome of the 1985 elections, ZH chose Mohammad Khan Junejo of Sindh to be his subservient prime minister, but removed Junejo in 1988 when he had started to become critical of ZH's government, in particular calling an inquiry into the Ojhri Camp disaster in Rawalpindi (Zaidi 2017).

From the very start of his regime, $\mathrm{ZH}$ actively promoted Pakistan as an ideological/Islamic state and certain geopolitical developments served his interests. In December 1981, he said "Pakistan is like Israel, which is an ideological state. Take out the Judaism from Israel and it will fall like a house of cards. Take Islam out of Pakistan and make it a secular state; it would collapse" (Burki 1986, 78). This served the dual purpose of pleasing Islamists at home-ZH's key supporters-and gaining international recognition at a time when Pakistan was playing a central role in the Afghan-Soviet War (Ahmed 2012). The Afghan-Soviet War played a crucial role, bringing Pakistan back into an alliance with the United States and its key allies, especially the Kingdom of Saudi Arabia. Pakistan's direct involvement in the Afghan-Soviet War helped ZH get more than \$7 billion in military and economic aid during 1981-1987 (Zahid 2011, 20). With this, he was able to fulfill his promises to modernize the armed forces and stabilize economy. For $\mathrm{ZH}$, this was a stroke of luck, he was willing to use all possible means to legitimize his rule and 
consolidate the legitimacy of his authoritarian regime. Pakistan's involvement in the Afghan-Soviet War played a central role in the fulfillment of Philip's second track of the authoritarian regime- "the political acceptability of the regime"-in which ZH gained legitimacy at home through external recognition of his government.

Pakistan's alliance with the United States and key Muslim states benefitted $\mathrm{ZH}$ immensely in terms of legitimacy and Islamization. During the 1980s, ZH's administration obtained external legitimacy through direct alliances that led to a sudden influx of military and non-military aid to Pakistan from the United States and Saudi Arabia (Weinbaum 1991, 71-85). Beyond providing much-needed financial assistance, it also allowed $\mathrm{ZH}$ to strengthen support from Islamists for his government. It was a win-win scenario for Islamists, who at that point were able to achieve political power and enabled $\mathrm{ZH}$ to obtain stronger domestic support. In this process, $\mathrm{ZH}$ brought to the fore the two most prominent Islamic parties (JI and JUI), in what Zaidi (2017) has called the beginning of the "mullah-military alliance" that still continues in Pakistan. Both parties also played a leading role in the Afghan-Soviet War through the recruitment of fighters from within Pakistan, for which they were rewarded with governmental positions (Ahmed 2012, 275-98). According to a study, "Pakistan's religious parties were nourished and strengthened by [ZH]" (Ahmed and Balasubramanian 2010, 93), in return $\mathrm{ZH}$ gained the full support of JI and JUI; for example, JI's student wing (Islami Jamiat-ul-Tulaba) became very active across the country restricting leftist student groups (CIA 1981, 7). The war in Afghanistan and mujahideen recruitment directly affected Islamization at home, for example, during that era alone more than 1,000 madrassas were opened across Pakistan.

While domestically, $\mathrm{ZH}$ was successful in gaining the support of Islamists, his Islamic and pan-Islamic rhetoric was also visible in his support of the Afghan refugees coming to Pakistan. Kanwal argues, "Zia's Afghan policy received strong support from [JI, JUI] and senior officers of the armed forces" (Kanwal 2015, 45). The Soviet invasion and the US-USSR proxy led to the deaths of over one million Afghans and forced the exodus of more than 6 million to nearly 100 countries, with the majority fleeing to neighboring Pakistan and Iran (Schöch 2008, 50; Zieck 2008, 253-4). Besides avoiding war and repression, the Afghans migrated because they did not want to live under the atheist government (Centlivres and Centlivres-Demont 1988). It is important to highlight that Pakistan was a key US partner in the resistance, comprised of mujahideen (holy warriors or the ones engaged in jihad), of the Soviets, 
therefore, Islamabad was willing to accept a huge influx of Afghan refugees. The official records report 2.8 million Afghan refugees arrived in 1985 , including many who were able to find work in Pakistan in the transport and agriculture sectors (Victor 1986, 444). In addition to strengthening ZH's support base within the country, the policy on Afghan refugees also projected Pakistan's image as a key player in global humanitarian efforts.

\section{CONCLUSION}

In sum, this study has found that the military regimes in both Pakistan and Bangladesh employed a range of authoritarian strategies to prolong their regimes. In the initial phases of their authoritarianism, all military rulers benefitted from the military's culture of subordination to superiors, therefore, they did not use Islam to achieve military coherence. However, they strategically used Islam in other survival strategies, such as for repression and social control, and legitimizing, to prolong their regimes. $\mathrm{ZH}$ and Ershad were particularly successful in gaining their military's support and this is particularly due to a culture of armed forces with a strong sense of obedience. In what Philip would call track 1, the generals from both countries did not have to use Islam to gain the support of their military colleagues. Islam, as we argue in this study was used more in other authoritarian strategies, such as for legitimacy, repression and social control. In track 2 , the military regimes moved on, working to gain public support. Although ZR did manage to gain popular support, he was unable to consolidate his power over military elites. Both $\mathrm{ZH}$ and Ershad, on the other hand, created several incentives for the armed forces, especially the top-ranked officers, to support their staying in power. While $\mathrm{ZH}$ used his absolute military power and shrewdness to legitimize his rule, for example through an ambiguous referendum, the two rulers in Bangladesh aimed for a genuine public support through their political system. If looked at through Philip's two tracks of military authoritarian regimes, we can say that $\mathrm{ZH}$ and Ershad not only consolidated their power with the military elites in their respective countries, they also both used Islam to gain legitimacy domestically and internationally. All three leaders worked on maximizing the use of Islamic discourse at home and pan-Islamism globally to legitimize their rules and all three rulers engaged and aligned themselves with parties of Islamic orthodoxy, portraying India as a "Hindu others" to enhance their own position. Unlike 
the two dictators in Bangladesh, $\mathrm{ZH}$ was able to benefit from the changing geopolitical dynamics that brought Pakistan to the center of the US-USSR proxy war in Afghanistan. With this, Pakistan appeared under the international spotlight as an important Islamic country.

\section{NOTES}

1. Through the 1956 Constitution, Islam was declared the state religion of Pakistan. Bangladesh started as a secular country in 1971 but in 1976, it dropped secularism from the state principles. In 1988, Bangladesh declared Islam as the state religion.

2. "The Constitution of the People's Republic of Bangladesh", 1979., Article 6 (2).

3. Ibid, Article 8(1).

4. Ibid, Article 8.

5. Ibid, Article 25(2).

6. "The Constitution of the People's Republic of Bangladesh." 1990.

7. In June 1978, "Jatiyobadi Front" was altered into the name of "Jatiyobadi Ganotantrik Dal (JAGODAL)," a Nationalist Democratic alliance.

8. For more details, see CIA Report (1983).

9. Zakat is an Islamic practice of alms giving that is among the five pillars of Islam.

\section{Acknowledgments}

A shorter version of this article was presented at the workshop on "Human Rights and Political Participation under Authoritarianism" held on September 21, 2018, Deakin University, Australia. We would like to thank Professor Ihsan Yilmaz of Deakin University (Australia) and Dr. Nabarun Roy of South Asian University (India) for their valuable inputs and comments on the paper. We also acknowledge the editorial support provided by Deakin University, Australia.

\section{REFERENCES}

Abhilash, T. 2012. "Role of the Bangladesh Army in the Political and Religious Affairs 1990-2009." PhD thesis, Jawaharlal Nehru University.

Abootalebi, Ali R. 1999. "Islam, Islamists, and Democracy." Middle East Review of International Affairs 3 (1): 14-24.

Ahamed, Emajuddin, and D. R. J. A. Nazneen. 1990. "Islam in Bangladesh: Revivalism or Power Politics?" Asian Survey 30 (8): 795-808.

Ahmed, Zahid Shahab. 2012. "Political Islam, the Jamaat-e-Islami, and Pakistan's Role in the Afghan-Soviet War, 1979-1988." In Religion and the Cold War: A Global Perspective, ed. Philip E. Muehlenbeck. Nashville: Vanderbilt University Press, 275298.

Ahmed, Zahid Shahab, and Rajeshwari Balasubramanian. 2010. Extremism in Pakistan and India: The Case of the Jamaat-e-Islami and Shiv Sena. Colombo: Regional Centre for Strategic Studies. 
Al-Sayyed, Maryam. 2015. "Democracy and Islam: The Incompatible Puzzle." In Religion and Representation: Islam and Democracy, eds. Ingrid Mattson, Paul Nesbitt-Larking, and Nawaz Tahir. Cambridge: Cambridge Scholars Publishing, 20-36.

Ali, Mukhtar Ahmad. 2000. Sectarian Conflict in Pakistan: A Case Study of Jhang. Colombo: Regional Centre for Strategic Studies.

Anckar, C. 2012. Religion and Democracy: A Worldwide Comparison. London: Routledge.

Aslam, Imran, and Kamran Asdar Ali. 2009. "Media Matters in Pakistan." Middle East Report, no. 251. https://merip.org/2009/06/media-matters-in-pakistan/.

Awan, Shehzadi Zamurrad. 2016. "Impact of Zia-ul-Haq's Gender Policies on Pakistani Society." Pakistan Journal of History and Culture 37 (1): 21-37.

Baxter, Craig, and M. Rashiduzzaman. 1981. "Bangladesh Votes: 1978 and 1979." Asian Survey 21 (4): 485-500.

Bhardwaj, Sanjay K. 2011. "Contesting Identities in Bangladesh: a Study of Secular and Religious frontiers." Working Paper, LSE Asia Research Centre.

Bhattacharya, Rupak. 1999. "Military Rule in Bangladesh: a Study on its Impact on Polity." PhD thesis, Jawaharlal Nehru University.

Bhuiyan, Jahid Hossain. 2017. "Secularism in the Constitution of Bangladesh." The Journal of Legal Pluralism and Unofficial Law 49 (2): 204-227.

Brasted, Howard V. 2012. "Islam and Identity in South Asia: At the Crossroads of Confusion and Confrontation?" In Islam in World Politics, eds. Lahoud, Nelly, and Anthony H. Johns. London: Routledge, 112-133.

Brooker, Paul. 2009. Non-democratic. Basingstoke: Palgrave Macmillan.

Burki, Shahid Javed. 1986. Pakistan: A Nation in the Making. Karachi: Oxford University Press.

Burki, Shahid Javed, Craig Baxter, Robert LaPorte, and Kamal Azfar. 1991. Pakistan under the Military: Eleven Years of Zia ul-Haq. Boulder: Westview Press; Lahore: Pak Book Corp.

Burki, Shireen Khan. 2016. "The Politics of Misogyny: General Zia-ul-Haq's Islamization of Pakistan's Legal System.” Contemporary Justice Review 19 (1): 103-119.

Centlivres, Pierre, and Micheline Centlivres-Demont, 1988. "The Afghan Refugee in Pakistan: An Ambiguous Identity." Journal of Refugee Studies 1 (2): 141-152.

Chen, Naiwei, and Tsai-Chen Yang. 2016. "Islam and Democracy-A Dynamic Perspective." Japanese Journal of Political Science 17 (3): 329-364.

CIA. 1981. Pakistan: Prospects for the Zia Government. Washington: Central Intelligence Agency.

CIA. 1983. Zia's Pakistan: The Politics of Survival. Washington: Central Intelligence Agency.

Esposito, John L., and John Obert Voll. 1996. Islam and Democracy. New York and Oxford: Oxford University Press.

Finer, Samuel E. 1997. The History of Government from the Earliest Times. New York and Oxford: Oxford University Press.

Finer, Samuel E. 2002. The Man on Horseback: The Role of the Military in Politics. New Jersey: Transaction.

Fish, M. Steven. 2002. "Islam and Authoritarianism." World Politics 55 (1): 4-37.

Franck, Hans Göran, and Klas Nyman. 2003. The Barbaric Punishment: Abolishing the Death Penalty. New York: Martinus Nijhoff Publishers.

Franda, Marcus. 1981. "Bangladesh after Zia: A Retrospect and Prospect." Economic and Political Weekly 16 (34): 387-394

Geddes, Barbara, Erica Frantz, and Joseph G. Wright. 2014. "Military Rule." Annual Review of Political Science 17 (1): 147-162. 
Gerschewski, Johannes. 2013. "The Three Pillars of Stability: Legitimation, Repression, and Co-optation in Autocratic Regimes." Democratization 20 (1): 13-38.

Hashmi, Salima, and Farida Batool. 2019. "Reframing the Contexts for Pakistani Contemporary Art." In Intersections of Contemporary Art, Anthropology and Art History in South Asia, eds. Sasanka Perera and Dev Nath Pathak. Cham: Palgrave Macmillan, 73-92.

Hashmi, Taj ul-Islam. 1994. "Islam in Bangladesh Politics." In Islam, Muslims and the Modern State: Case Studies of Muslims in Thirteen Countries, eds. Hussin Mutalib and Taj ul-Islam Hashmi. New York: St. Martin's Press, 103-104.

Hechter, Michael. 2009. "Legitimacy in the Modern World." American Behavioral Scientist 53 (3): 279-288.

Herb, Michael. 2005. "No Representation without Taxation? Rents, Development, and Democracy." Comparative Politics 37 (3): 297-316.

Hoodbhoy, Pervez. 2016. "Could Pakistan Have Remained Pluralistic?" In Faith-Based Violence and Deobandi Militancy in Pakistan, eds. Jawad Syed, Edwina Pio, Tahir Kamran and Abbas Zaidi. London: Macmillan Publishers, 35-64.

Hossain, Akhand Akhtar. 2015. "Contested National Identity and Political Crisis in Bangladesh: Historical Analysis of the Dynamics of Bangladeshi Society and Politics." Asian Journal of Political Science 23 (3): 366-396.

Hossain, Ishtiaq, and Noore Alam Siddiquee. 2004. "Islam in Bangladesh Politics: The Role of Ghulam Azam of Jamaat-I-Islami." Inter-Asia Cultural Studies 5 (3): 384399. https://www.dawn.com/news/1364410.

Hussain, Iqbal. 2007. "Suffering for art in Pakistan." The Guardian, 7 August 2007. https://www.theguardian.com/world/2007/aug/17/pakistan-prostitution.

Imran, Rahat, and Imran Munir. 2018. "Defying Marginalization: Emergence of Women's Organizations and the Resistance Movement in Pakistan: A Historical Overview." Journal of International Women's Studies 19 (6): 132-156.

Iqbal, Nasir. 2014. "Marching on the Capital-A History." Dawn, August 17, 2014.

Islam, Syed Serajul. 1984. "The State in Bangladesh under Zia (1975-81)." Asian Survey 24 (5): 556-573.

Ispahani, Farahnaz. 2017. "Pakistan's Descent into Religious Intolerance." Hudson Institute, Last Modified, 1 March 2017. https://www.hudson.org/research/13492pakistan-s-descent-into-religious-intolerance.

Kabir, Bhuian MD. Manohar. 1999. Politics of Military Rule and Dilemmas of Democratisation in Bangladesh. New Delhi: South Asian Publishers.

Kanwal, Lubna. 2015. "Zia, Islam and Politics of Legitimacy." Al-Adwa 43 (30): 39-52.

Kasparov, Garry, and Thor Halvorssen. 2017. "Why the Rise of Authoritarianism is a Global Catastrophe." The Washington Post, 13 February 2017. https://www. washingtonpost.com/news/democracy-post/wp/2017/02/13/why-the-rise-ofauthoritarianism-is-a-global-catastrophe/.

Kaufman, Michael T. 1982. "Pakistan Accused of Rights Abuses." The New York Times, 12 January 1982. https://www.nytimes.com/1982/01/13/world/pakistan-accused-ofrights-abuses.html.

Khan, Zillur R. 1981. "Politicization of the Bangladesh Military: A Response to Perceived Shortcomings of Civilian Government." Asian Survey 21 (5): 551-564.

Khan, Zillur R. 1985. "Islam and Bengali Nationalism." Asian Survey 25 (8): 834-851.

Kienscherf, M. 2016. "Beyond Militarization and Repression: Liberal Social Control as Pacification." Critical Sociology 42 (7-8): 1179-1194.

Kochanek, S. A. 1993. Patron-client Politics and Business in Bangladesh. Thousand Oaks: Sage Publications, 58-63. 
Lewis, Bernard. 1988. The Political Language of Islam. Chicago: University of Chicago Press.

Linz, Juan. 1964. “An Authoritarian Regime: The Case of Spain.” In Cleavage, Ideologies, and Party Systems, eds. Erik Allardt and Yrko Littunene. Helsinki: The Academic Bookstores, 251-283.

Maniruzzaman, Talukdar. 1990. "Bangladesh Politics: Secular and Islamic Trends." In Religion, Nationalism and Politics in Bangladesh, ed. Rafiuddin Ahmed. New Delhi: South Asian Publishers, 63-91.

Mannan, Md Abdul. 2015. "Islamic Identity as a Domestic Variable in Bangladesh's Foreign Policy towards India and Pakistan under the BNP's Rule." PhD thesis, The University of Melbourne.

March, Andrew F. 2003. "State Ideology and the Legitimation of Authoritarianism: The Case of Post-Soviet Uzbekistan." Journal of Political Ideologies 8 (2): 209-232.

Mayer, Robert. 2001. "Strategies of Justification in Authoritarian Ideology." Journal of Political Ideologies 6 (2): 147-168.

Mishra, Jitendra. 1981. "Military Regimes in Bangladesh and Pakistan: Strategies of Sustenance and Survival." India Quarterly 37 (4): 522-546.

Nordlinger, Eric A. 1977. Soldiers in Politics: Military Coups and Governments. (PrenticeHall contemporary comparative politics series). Englewood Cliffs: Prentice Hall.

Omelicheva, Mariya Y. 2016. "Authoritarian Legitimation: Assessing Discourses of Legitimacy in Kazakhstan and Uzbekistan." Central Asian Survey 35 (4): 481-500.

Özler, Hayrettın, and Yildirim Ergün. 2008. "Islam and Democracy: A False Dichotomy." Insight Turkey 10 (3): 87-99.

Pattanaik, Smruti S. 2012. "Consonance and Dissonance: Issues and Trends in India Bangladesh Relations" in Four Decades of India-Bangladesh Relations." In Historical Imperatives and Future Direction, ed. Smruti S. Pattanaik. Delhi: Gyan Publishing House, 22. Peace 24 (2): 25-35.

Perlmutter, Amos. 1977. The Military and Politics in Modern Times: On Professionals, Praetorians, and Revolutionary Soldiers. New Haven: Yale University Press.

Philip, George. 1984. "Military-Authoritarianism in South America: Brazil, Chile, Uruguay and Argentina." Political Studies 32 (1): 1-20.

Pipes, Daniel. 1983. In the Path of God: Islam and Political Power. New York: Basic Books.

Qadeer, Mohammad. 1997. "The Evolving Structure of Civil Society and the State in Pakistan." The Pakistan Development Review 36 (4): 743-762.

Rashiduzzaman, M. 1978. "Bangladesh in 1977: Dilemmas of the Military Rulers." Asian Survey 18 (2): 126-134.

Razi, G. Hossein. 1990. "Legitimacy, Religion, and Nationalism in the Middle East." American Political Science Review 84 (1): 69-91.

Rehman, I. A. 2017. “40 years of Zia: How Zia redefined Pakistan.” Dawn, 2 July 2017. https://www.dawn.com/news/1342697.

Riaz, Ali. 2018. "More Than Meets the Eye: The Narratives of Secularism and Islam in Bangladesh." Asian Affairs 49 (2): 301-318.

Rizvi, H. 1993. Pakistan and the Geostrategic Environment: A Study of Foreign Policy. London: Macmillan Press Ltd, Springer.

Robinson, Francis. 1989. The Cambridge Encyclopedia of India, Pakistan, Bangladesh, Sri Lanka, Nepal, Bhutan and the Maldives. Cambridge: Cambridge University Press, 219-222.

Rørbæk, Lasse Lykke, Svend-Erik Skaaning, and Jakob Tolstrup. 2014. "Autocratic Regime Duration and State Repression." European Consortium for Political Research. https://ecpr.eu/Filestore/PaperProposal/df68944a-74ad-4161-a894-ea56f7fcc1e1.pdf. 
Sachedina, Abdulaziz. 2001. The Islamic Roots of Democratic Pluralism. New York: Oxford University Press.

Savory, Roger. 1989. "Islam and Democracy: The Case of the Islamic Republic of Iran." In The Islamic World: From Classical to Modern Times: Essays in Honor of Bernard Lewis, eds. Clifford Edmund Bosworth, et al. Princeton: Darwin Press, 821-843.

Schöch, Rüdiger, 2008. "UNHCR and the Afghan Refugees in the Early 1980s: Between Humanitarian Action and Cold War Politics." Refugee Survey Quarterly 27 (1): 45-57.

Sen, Rangalal. 1994. "The Movement for Restoration of Democracy in Bangladesh 1982-1990: A Theoretical Framework and Social Background." In Society, Polity and Economy of Bangladesh, ed. S. R. Chakravarty. New Delhi: Har-Anand Publications, 122.

Shuja, Sharif. 2007. "Pakistan: Islam, Radicalism and the Army." International Journal on World Peace 24 (2): 25-35.

Smith, Donald Eugene. 1970. Religion and Political Development: An Analytical Study. New York: Little, Brown.

Tamimi, Azzam S. 1997. "Democracy in Islamic Political Thought." Encounters-Leicester 3: 21-44. See https://core.ac.uk/download/pdf/14517149.pdf (Retrieved by December 17, 2018).

The Asian Recorder. 18-24 June 1990.

The Bangladesh Observer. 2 May 1976.

The Constitution of the People's Republic of Bangladesh. 1979.

The Constitution of the People's Republic of Bangladesh. 1990.

Uddin, Sufia M. 2006. Constructing Bangladesh: Religion, Ethnicity, and Language in an Islamic Nation. Chapel Hill: University of North Carolina Press.

Victor, Jean-Christophe. 1986. “Afghanistan: A Protracted Conflict." Security Dialogue 17 (1): 437-446.

Warde, Ibrahim. 2010. Islamic Finance in the Global Economy. Edinburgh: Edinburgh University Press.

Wasti, Tahir. 2009. The Application of Islamic Criminal Law in Pakistan: Sharia in Practice. Boston: Brill.

Weinbaum, Marvin G. 1991. "War and Peace in Afghanistan: The Pakistani Role." Middle East Journal 45 (1): 71-85.

Wolf, S. 2013. "Civil-Military Relations and Democracy in Bangladesh." Spotlight South Asia, Special Issue, Foundation for Applied Political Science of South Asia (APSA), Heidelberg.

Yaseen, Zahid, Muhammad Abrar Ahmad, and Tahir Mahmood Butt. 2016. "Hypothetical Political System of Martial Laws: A Case Study of General Zia-ul-Haq." South Asian Studies: A Research Journal of South Asian Studies 29 (1): 122-132.

Yasmin, Lailufar. 2013. "Religion and After: Bangladeshi Identity Since 1971." Open Democracy 19.

Zahid, Masood Akhtar. 2011. "Dictatorship in Pakistan: A Study of the Zia Era (19771988)." Pakistan Journal of History and Culture 32 (1): 1-27.

Zaidi, S. Akbar. 2017. "Special Report: Darkness Descends 1977-1988." The Dawn, 1 November 2017.

Zaidi, Syed M. Zulqurnain. 2003. The Emergence of Ulema in the Politics of India and Pakistan 1918-1949: A Historical Perspective. Lincoln: Writers Club Press.

Zhao, Dingxin. 2009. "The Mandate of Heaven and Performance Legitimation in Historical and Contemporary China." American Behavioral Scientist 53 (3): 416-433.

Zieck, Marjoleine. 2008. "The Legal Status of Afghan Refugees in Pakistan, a Story of Eight Agreements and Two Suppressed Premises." International Journal of Refugee Law 20 (2): 253-272. 